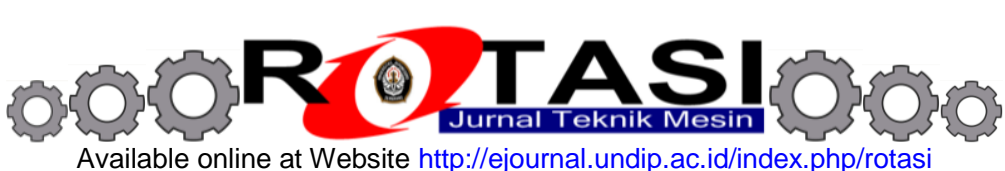

\title{
PENGEMBANGAN DISAIN TUNGKU BAHAN BAKAR KAYU RENDAH POLUSI DENGAN MENGGUNAKAN DINDING BETON SEMEN
}

\author{
*Bambang Yunianto, Nazarudin Sinaga, Ramanda S.A.K \\ Jurusan Teknik Mesin, Fakultas Teknik, Universitas Diponegoro \\ Jl.Prof.Sudharto, Tembalang, Semarang, Indonesia \\ *Email: b_yunianto@undip.ac.id
}

\begin{abstract}
ABSTRAK
Kelangkaan minyak tanah dipasaran dan harga yang mahal mendorong masyarakat kususnya masyarakat pedesaan kembali ke penggunaan kayu bakar untuk keperluan memasak. Hal ini mendorong peningkatan polusi asap, akibat penggunaan tungku yang sederhana. Dengan penelitian ini dikembangkan disain tungku yang lebih efisien dan rendah polusi. Dalam penelitian ini digunakan tungku modifikasi dengan dinding tungku dari beton cor semen dan isolator udara dalam dinding. Pengujian tungku dilakukan dengan memanaskan air hingga $98 \mathrm{C}$ pada dua panci $(29 \mathrm{~cm}$ dan $37 \mathrm{~cm})$ serta menggunakan kayu bakar pada dua tingkat kekeringan (16\% dan $24 \%$ ). Dari hasil pengujian diketahui bahwa pemanasan air dengan panci kecil $(29 \mathrm{~cm})$ dan kayu kering $(16 \%)$ menghasilkan efisiensi terbaik $(20 \%)$. Sedangkan pada panci besar $(37 \mathrm{~cm})$ dan kayu basah $(24 \%)$ menghasilkan efisiensi terendah $16 \%$. Dari pengujian tersebut diatas, tungku dinding beton cor semen, tetap masih lebih tinggi jika dibandingkan dengan tungku tradisional yang hanya mempunyai efisiensi $13 \%$. Mengkaji data pengujian yang dihasilkan, kami tim peneliti berkesimpulan bahwa prototipe tungku ini layak digunaan di masarakat pedesaan dan industri kecil.
\end{abstract}

Kata kunci: Tungku, pembakaran, efisiensi, beton cor, isolator udara.

\section{PENDAHULUAN}

\subsection{Latar belakang}

Industri kecil dan menengah diberbagai bidang produksi relatif masih berjalan dengan baik, walau ada kendala ketersediaan bahan bakar minyak tanah yang mulai sulit ditemui dipasaran, dan mahal. Pelaku industri kecil demikian juga masarakat kota umumnya menggunakan bahan bakar minyak tanah dan sekarang banyak beralih ke LPG. Namun bagi industri kecil dan masarakat pedesaan bahan bakar minyak ataupun LPG dirasakan terlalu mahal, apalagi subsidi pemerintah cenderung berkurang. Juga faktor kepercayaan masarakat terhadap keamanan penggunaan LPG dirasa masih ada. Sehingga program konversi minyak ke LPG belum berhasil maximal kususnya di industri kecil dan masarakat pedesaan. Untuk mengatasi permasalahan mahalnya energi minyak dan gas, dan mempertahankan rasa aman terhadap penggunaan bahan bakar, masarakat pedesaaan dan industri kecil cenderung kembali ke tungku bahan bakar kayu.

Bahan bakar kayu merupakan salah satu bahan bakar Biomassa, yang paling banyak di gunakan di Indonesia. Sebagai bahan bakar, biomassa memiliki beberapa keuntungan terutama sifat terbarukannya, yaitu bahan bakar tersebut dapat diproduksi ulang, sehingga pelestarian energi dan pelestarian alam dapat dipertahankan. Bahan bakar kayu untuk tungku mudah didapat dan murah. Namun karena teknologi tungku yang dipakai sederhana, maka pencemaran udara karena asap dan gas-gas keluaran lainnya masih tinggi. Mengingat data dari kementerian Energi Sumber Daya Mineral (ESDM) yang menunjukkan bahwa penggunaan bahan bakar dari Biomassa (kayu) cukup tinggi (tabel 1), maka pencemaran lingkungan secara Nasional akibat penggunaan bahan bakar kayu juga masih tinggi. Salah satu cara meminimalkan pencemaran ini, perlu mendisain atau memodifikasi tungku bahan bakar kayu yang lebih efisien dan rendah polusi. Konsep disain tungku yang efisien adalah menciptakan proses pembakaran yang sempurna. Pembakaran sempurna bahan bakar dapat dicapai jika suhu ruangan, bahan bakar dan rasio udara bahan bakar pada kondisi yang diinginkan.

Untuk pembakaran yang sempurna, suhu ruangan dan kayu harus tinggi serta ukuran kayu kecil dan kering. Untuk mendapatkan suhu ruang bakar yang tinggi, maka dinding ruang bakar didisain dengan menggunakan bahan bertahanan panas tinggi (isolator). Bahan isolator ini sangat penting untuk mencegah panas hilang, sehingga suhu ruang bakar tetap dapat dipertahankan tinggi. Rasio bahan bakar - udara yang tepat untuk pembakaran sempurna perlu diatur dengan membuat sirkulasi udara dalam ruang bakar berlangsung baik. Disain panjang pendeknya saluran udara menentukan laju aliran udara (sirkulasi alami) dalam ruang bakar yang selanjunya mempengaruhi sempurna tidaknya proses pembakaran. Pada disain tungku kayu bakar, dimensi, bahan dan suhu ruang bakar, serta ukuran bahan bakar kayu merupakan kajian penelitian ini. Dari kajian ini diharapkan akan diperoleh disain tungku yang mempunyai efisiensi tinggi dan mempunyai nilai kompetitif dengan jenis tungku dan kompor lainnya. 
Tabel 1. Konsumsi Energi Indonesia berdasarkan tipenya

\begin{tabular}{|ccccccccccc|}
\hline Year & Biomass & Coal & $\begin{array}{c}\text { Natural } \\
\text { Gas }\end{array}$ & Fuel & $\begin{array}{c}\text { Other } \\
\text { Petroleum } \\
\text { Product }\end{array}$ & Briquette & LPG & Elictricity & Total \\
\hline $\mathbf{2 0 0 0}$ & 269,042 & 36,060 & 87,214 & 315,272 & 13,435 & 85 & 8,261 & 48,555 & 777,925 \\
\hline 2001 & 268,953 & 37,021 & 82,235 & 328,203 & 25,712 & 78 & 8,280 & 51,841 & 802,325 \\
\hline 2002 & 270,207 & 38,698 & 80,885 & 325,202 & 22,688 & 83 & 8,744 & 53,418 & 799,926 \\
\hline $\mathbf{2 0 0 3}$ & 271,974 & 68,264 & 90,227 & 321,384 & 23,533 & 77 & 8,766 & 55,473 & 839,748 \\
\hline $\mathbf{2 0 0 4}$ & 271,765 & 55,344 & 85,459 & 354,317 & 37,716 & 80 & 9,187 & 61,393 & 875,261 \\
\hline $\mathbf{2 0 0 5}$ & 270,043 & 65,744 & 86,634 & 338,375 & 29,614 & 94 & 8,453 & 65,644 & 864,601 \\
\hline $\mathbf{2 0 0 6}$ & 276,271 & 89,043 & 83,221 & 311,913 & 41,126 & 94 & 9,414 & 69,071 & 880,153 \\
\hline $\mathbf{2 0 0 7}$ & 275,126 & 121,904 & 80,178 & 314,248 & 39,873 & 89 & 10,925 & 74,376 & 916,720 \\
\hline $\mathbf{2 0 0 8}$ & 277,874 & 74,939 & 85,311 & 312,190 & 16,658 & 155 & 15,718 & 79,138 & 861,984 \\
\hline $\mathbf{2 0 0 9}$ & 279,145 & 82,587 & 118,452 & 333,962 & 25,922 & 219 & 25,259 & 82,567 & 948,112 \\
\hline
\end{tabular}

Penelitian ini adalah tindak lanjut dari penelitian tahun lalu (tahun 2010), yaitu tungku bahan bakar kayu yang menggunakan isolator abu kayu dan glass wool. Hasil pengujian dari penggunaan kedua jenis isolator itu mampu menghasilkan peningkatan efisiensi tungku $30 \%$ hingga $40 \%$, jika dibandingkan dengan tungku tradisional (Bambang Yunianto, 2010). Namun dari hasil pengujian terhadap tungku tersebut mempunyai kendala, yaitu tungku dengan isolator glass wool relatif mahal dan mudah terbakar, jika pemasangan isolatornya kurang sempurna. Sementara tungku dengan isolator abu kayu, mengalami hambatan ketersedian abu kayu yang terbatas jika produksi tungku dalam jumlah besar. Disamping kendala isolator tersebut, juga bahan dinding tungku dari logam (plat besi) mudah terjadi korosi dan kurang awet. Jika diinginkan disain yang lebih sempurna dipilih bahan dari logam baja tahan karat, sehingga menjadikan harga tungku menjadi mahal. Untuk mengatasi hambatan diatas perlu dicari bahan kontruksi dan jenis isolator yang mudah didapat dan murah. Untuk itu kami mempertimbangkan pemakaian beton semen sebagai kontruksi tungku dan udara sebagai isolator dengan mengacu disain tungku yang digunakan pada penelitian sebelumnya. Target dari hasil pengujian ini adalah mengetahui efisiensi tungku dan membandingkan dengan efisiensi tungku pada penelitian sebelumnya, dengan target prestasi tungku yang sama atau idak begitu jauh dengan prestasi tungku logam yang sudah diteliti sebelumnya dengan kelebihan harga yang murah dan mudah dibuat.

\subsection{Proses pembakaran}

Pembakaran sempurna adalah proses pembakaran dimana gas buang yang dihasilkan terdiri dari gas CO2 dan Air. Sebaliknya pembakaran tidak sempurna , gas hasil pembakaran disamping dua gas tersebut, terdapat juga gas-gas lain hasil dari pembakaran tidak sempurna, seperti gas $\mathrm{CO}, \mathrm{HC}, \mathrm{NOx}$ dan partikel padat. Untuk pembakaran bahan bakar padat, partikel padat umumnya dalam bentuk abu, seperti halnya hasil sisa pembakaran batu bara dan kayu bakar.

Pembakaran kayu tidak dapat terjadi langsung seperti pada bahan bakar cair ataupun gas. Pada kayu, proses pembakaran melalui dua tahap yaitu pirolisis dan pembakaran. Pada proses pirolisis terjadi reaksi endotermal, artinya kayu yang dipanasi akan menaikkan temperatur kayu, dari suhu ruang hingga 500 C (F.L. Browne, 2006). Pada kondisi ini terjadi pelepasan gas/uap dan bahan-bahan lain yang menguap. Setelah penguapan gas-gas tersebut dan temperatur kayu mencapai temperatur pembakaran, maka pembakaran akan berlangsung dengan ditandainya nyala api dari kayu. Warna nyala memberikan indikasi energi panas yang dihasilkan. Makin terang nyala api energi panas pembakaran makin tinggi. Kayu yang benar-benar kering akan meningkatkan efisiensi pembakaran dan mempersingkat waktu penyalaan.

Efisiensi pembakaran bahan bakar sangat tergantung dari proses pencampuran bahan bakar dan oksigen. Pada bahan bakar cair ataupun gas, proses pencampuran bahan bakar -udara relatif lebih mudah sehingga partikel padat yang dihasilkan relatif sedikit, yaitu berupa jelaga yang menempel pada dinding ruang bakar. Sedangkan pada bahan bakar padat proses terjadinya pencampuran bahan bakar -udara jauh lebih sulit, sehingga banyak abu yang dihasilkan. $\mathrm{Abu}$ atau residu hasil pembakaran bahan bakar padat selain akibat terjadinya pembakaran tidak sempurna , juga diakibatkan oleh komposisi bahan bakar yang mengandung bermacam-macam bahan yang merupakan bahan tidak bisa 
terbakar. Oleh karena itu proses pembakaran dalam tungku bahan bakar kayu memerlukan persyaratan yang lebih komplek dari pada pembakaran bahan bakar cair.

Pembakaran sempurna bahan bakar kayu akan terjadi jika memenuhi beberapa persaratan berikut (Peter Scott, 2005):

1) Suhu ruang bakar dan kayu bakar tinggi, kurang lebih $650^{\circ} \mathrm{C}$

Suhu ruang bakar dan suhu kayu bakar tinggi diperlukan untuk melepaskan uap air dan gas-gas yang bisa menguap dari kayu, sehingga mempermudah pembakaran dapat berlangsung sempurna. Untuk mempertahankan suhu ruang bakar tinggi, maka perlu dipasang isolator pada dinding, sehingga kerugian panas ke lingkungan dapat diperkecil. Isolator dipilih yang mempunyai konduktansi rendah dan memiliki kemampuan memantulkan panas yang tinggi. Pada disain Dinding tungku dari beton cor semen bukan isolator yang baik, sehingga untuk meningkatkan kwalitas hambatan panas (isolator) maka dalam dinding dibuat rongga -rongga udara. Udara mempunyai nilai konduktansi (isolator) yang rendah dan tersedia dialam tanpa diperlukan biaya untuk memanfaatkannya.

2) Ukuran kayu dibuat kecil dan kering.

Ukuran kayu kecil dimaksudkan untuk memperluas permukaan kayu, sehingga kontak dengan udara dapat berlangsung baik. Hal ini dapat meningkatkan rasio jumlah udara bahan bakar (AFR) dan proses pencampuran udara bahan bakar berlangsung lebih sempurna.

3) Sirkulasi udara dalam ruang bakar berlangsung baik.

Kecukupan udara untuk proses pembakaran perlu diciptakan sehingga pembakaran kayu bakar berlangsung baik. Ketidak cukupan udara akan berakibat banyaknya bahan bakar yang tidak terbakar. Sebaliknya, udara berlebihan akan mengakibatkan suhu ruang bakar yang rendah, sehingga banyak asap yang terjadi akibat dari efisiensi pembakaran rendah. Untuk menciptakan sirkulasi udara yang sesuai dengan kebutuhan proses pembakaran perlu didisain dimensi dan tinggi ruang bakar yang memungkinkan tarikan udara alami dalam ruang bakar dapat berlangsung baik. Disamping itu pengaturan tinggi rendahnya panci terhadap ujung tungku perlu dicari posisi optimumnya untuk meyakinkan terjadinya aliran udara dalam ruang bakar.

4) Kandungan air (kelembaban) kayu

Kandungan air dalam kayu akan berpengaruh terhadap nilai kakalor kayu, yang selanjutnya mempengaruhi proses pembakaran. Kayu kering mempunyai nilai kalor tinggi dan sebaliknya kayu basah mempunyai nilai kalor rendah seperti ditunjukkan pada gambar grafik berikut.

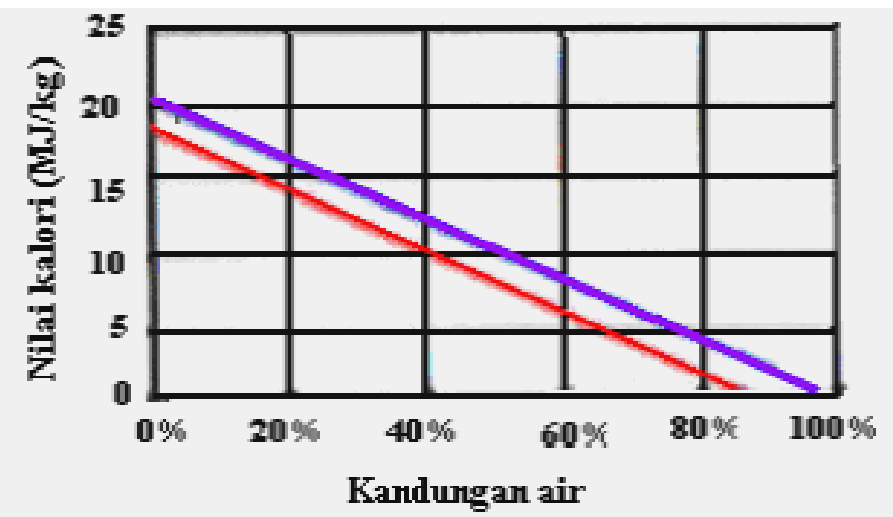

Gambar 1. Kandungan air dan Nilai Kalor bahan bakar kayu Garis merah = LHV, garis biru =HHV

\section{METODOLOGI PENELITIAN}

\subsection{Desain alat uji/Tungku}

Disain alat uji atau Tungku bahan bakar kayu pada prinsipnya adalah modifikasi dan mengembangkan tungkutungku bahan bakar kayu yang sudah ada. Kontruksi tungku dibuat dari beton cor semen dengan ukuran panjang, lebar dan tinggi masing-masing 40x50x50 cm . Diameter ruang bakar $18 \mathrm{~cm}$. Dalam dinding tungku diberikan rongga udara yang berfungsi sebagai isolator. Penepatan panci pada jarak $0,8 \mathrm{~cm}$ diatas permukan atas tungku. Instalasi tungku uji dan kelengkapannya secara skema ditunjukkan dengan Gambar 2 Pengukuran dilakukan pada dua panci dengan ukuran $29 \mathrm{~cm}$ dan $37 \mathrm{~cm}$ serta kondisi dua tingkat kelembaban kayu yang berbeda (20\% dan $16 \%$ ). Temperatur dinding luar $\mathrm{T}_{\mathrm{p} 1}, \mathrm{~T}_{\mathrm{p} 2}$ dan temperaratur ruang bakar $\mathrm{T}_{\mathrm{d} 1}, \mathrm{~T}_{\mathrm{d} 2}$ diukur dengan menggunakan termometer infra merah.Temperatur permukaan dinding diukur dengan menembakkan sinar infra merah ke permukaan dinding, sementara temperatur dinding ruang bakar dilakukan melalui lubang yang ada pada dinding hingga menembus dinding ruang bakar, seperti ditunjukkan pada Gambar 3. 


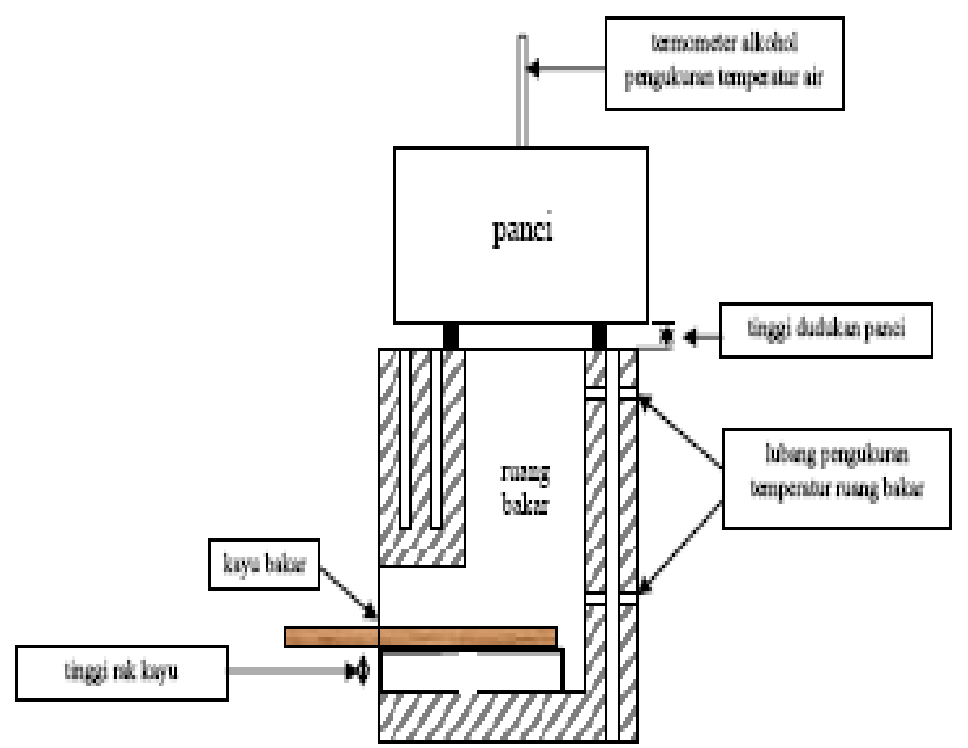

Gambar 2. Skema tungku bahan bakar kayu

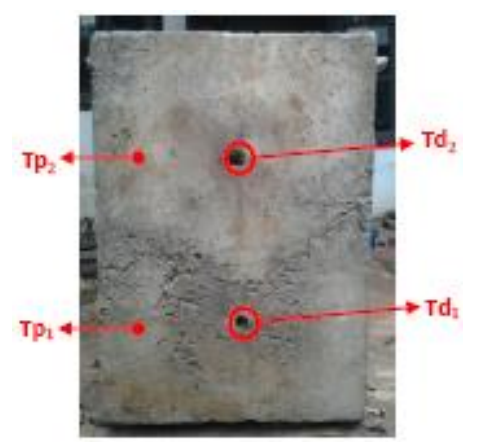

Gambar 3. Titik-titik dan Lubang pengukur temperatur dinding tungku.

\subsection{Langkah pengujian}

Pengujian dilakukan dengan mengambil data jumlah kayu bakar yang terpakai dalam proses pembakaran (dalam gram), jumlah air yang dipamskan, temperatur air akhir dan temperatur dinding luar ataupun temperatur dinding dalam ruang bakar. Pengambilan data dilakukan setelah kondisi tungku dalam kondisi stedi. Kayu sisa dan abu dikeluarkan dan diganti dengan kayu yang baru dengan timbangan yang telah ditentukan. Berat kayu yang terbakar (dalam gram) dihitung dari berat awal dikurangi berat sisa kayu untuk periode pemanasan air sebanyak 8 liter. Pemanasan air diakiri setelah temperatur air mendekati mendidih (98 C). Pengukuran berat kayu terbakar digunakan untuk mengetahui konsumsi bahan bakar kayu per volume air atau yang disebut konsumsi bahan bakar spesidik (persamaan 1) dan juga efisiensi tungku (persamaan 2). Efisiensi tungku adalah perbandngan jumlah panas yang berguna untuk memanaskan hingga temperatur tertentu (98 C) terhadap jumlah panas masukkan dari bahan bakar kayu. Konsumsi spesifik (SC) dan efisiensi tungku $(\boldsymbol{\eta})$, merupakan parameter prestasi tungku yang dinyatakan persamaan 1, dan 2 berikut:

$$
\begin{aligned}
& \mathrm{SC}=\mathrm{m}_{\mathrm{b}} / \mathrm{V}_{\mathrm{air}} \\
& \eta=\mathrm{m}_{\mathrm{a}} \cdot \mathbf{C} \cdot\left(\mathbf{T}_{\mathrm{d}}-\mathrm{T}_{\mathrm{a}}\right) / \mathbf{m}_{\mathrm{b}} \cdot \mathbf{N K}
\end{aligned}
$$

Keterangan:

$$
\begin{array}{ll}
\mathrm{m}_{\mathrm{a}}, \mathrm{m}_{\mathrm{b}} & =\text { Masa air, masa bahan bakar } \\
\mathrm{C} & =\text { Panas jenis air } \\
\mathrm{Td} & =\text { Temperatur didih air } \\
\mathrm{Ta} & =\text { Temperatur air awal } \\
\mathrm{NK} & =\text { Nilai kalor }
\end{array}
$$

Adapun data-data pengukuran temperatur dinding luar dan dinding ruang bakar digunakan untuk menganalisa kerugian kalor dari tungku. Pengujian dilakukan secara bergantian dari kayu basah (kelembaban $20 \%$ ) ke kayu kering (kelembaban $16 \%$ ). Untuk pengambilan data temperatur dilakukan dengan dua cara yaitu, pembakaran kayu bakar 
dilakukan saat kondisi tungku masih dingin (cool start) dan cara kedua setelah tungku sudah dalam keadaan panas (hot start). Masing-masing cara pengujian digunakan pada dua jenis panci, besar $(37 \mathrm{~cm})$ dan kecil $(29 \mathrm{~cm})$.

\section{HASIL DAN PEMBAHASAN}

Hasil pengujian ditunjukkan dengan Gambar 4 s.d 6, yang menunjukkan prestasi tungku bahan bakar kayu, yang dinyatakan dengan konsumsi bahan bakar spesifik dan efisiensi tungku. Hasil pengujian dipengaruhi oleh tingkat kandungan air pada kayu dan ukuran panci pemanas air.

\subsection{Konsumsi spesifik terhadap variasi pengujian}

Yang dimaksud variasi pengujian adalah digunakannya dua jenis kayu (basah dan kering), dua ukuran panci (besar dan kecil) dan cara pengoperasian tungku (hot start dan cool start). Dari Gambar 4, diketahui bahwa konsumsi spesifik bahan bakar akan meningkat dengan makin keringnya kayu. Pada kayu basah (kandungan air $24 \%$ ) dan pada panci kecil (diameter $29 \mathrm{~cm}$ ) menghasilkan konsumsi spesifik $101 \mathrm{gr} / \mathrm{lt}$, sedangkan pada kayu kering (kandungan air 16 $\%$ ) terjadi penurunan konsumsi spesifik menjadi 92 gr/lt. Sementara pada panci besar (diameter $37 \mathrm{~cm}$ ) konsumsi spesifik terjadi peningkatan menjadi1 10 gr/lt (kayu basah ) dan 97 gr /lt untuk kayu kering.

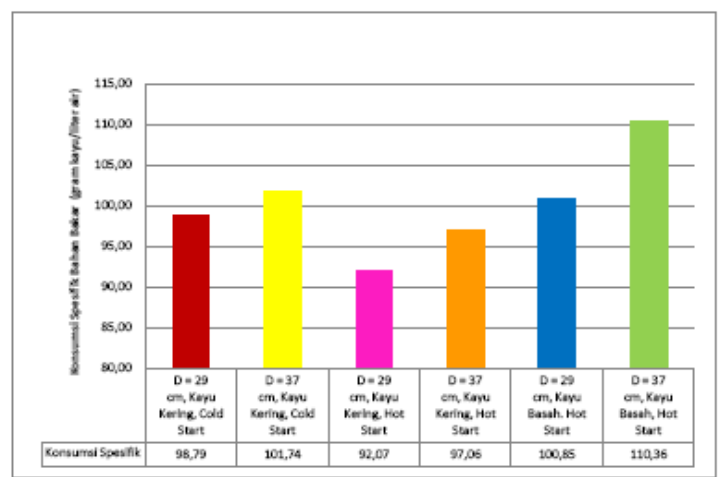

Gambar 4. Konsumsi spesifik tungku terhadap variasi pengujian

Hal ini sesuai dengan nilai kalor kayu dipengaruhi oleh kandungan air seperti ditunjukkan pada Gambar 1. Makin kering kayu maka terjadi peningkatan nilai kalornya, sehingga menurunkan konsumsi spesifiknya. Prestasi tungku juga dipengaruhi oleh saat dimulainya operasi tungku. Tungku yang masih dingin akan berbeda prestasinya dengan saat tungku sudah panas. Dari Gambar 4 juga ditunjukkan perbedaan operasi tungku saat dingin (cold start) dan saat panas (hot start). Konsumsi spesifik pada saat operasi dingin adalah $101 \mathrm{gr} / \mathrm{lt}$, lebih tinggi dari pada saat operasi pada kondisi panas sebesar $92 \mathrm{gr} / \mathrm{lt}$. Jika dibandingkan dengan pengujian pada tungku tradisional, konsumsi bahan bakar kayu mencapai 177,5 gram/L air, yang masih lebih tinggi dari pada tungku dengan dinding cor semen.

\subsection{Efisiensi Tungku terhadap variasi pengujian.}

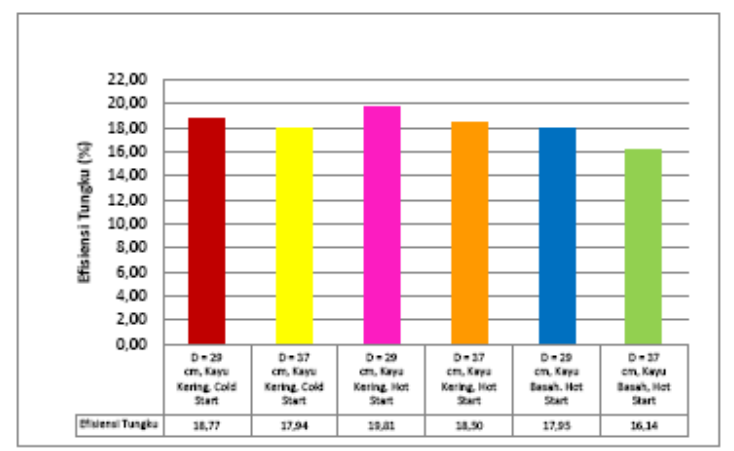

Gambar 5. Efisiensi tungku terhadap variasi pengujian

Dari Gambar 5 diatas dapat diketahui bahwa efisiensi tungku setara dengan konsumsi spesifik. Dengan konsumsi spesifik yang rendah (hemat bahan bakar) berarti juga akan menghasilkan efisiensi yang tinggi, demikian pula sebaliknya. Efisiensi tertinggi (20\%), terjadi pada pemanasan air dengan panci kecil (29 cm) dan kayu kering (16\%) Sedangkan pada panci besar $(37 \mathrm{~cm})$ dan kayu basah $(24 \%)$ menghasilkan efisiensi terendah $16 \%$. Dari pengujian tersebut diatas, tungku dinding beton cor semen, tetap masih lebih tinggi jika dibandingkan dengan tungku tradisional yang hanya mempunyai efisiensi $13 \%$. 


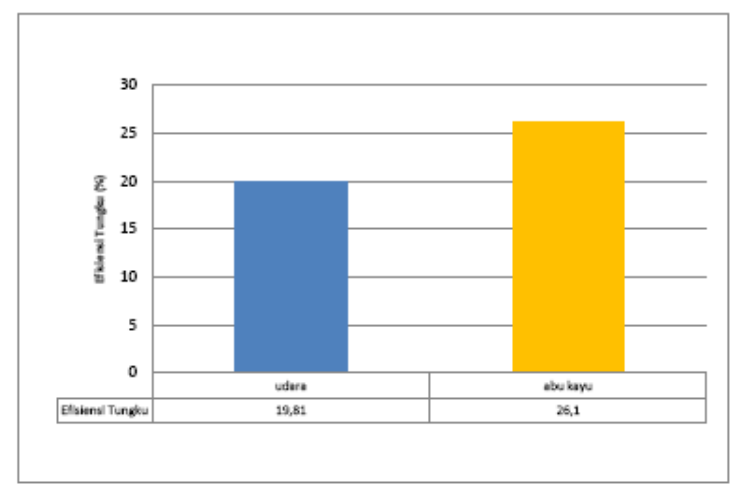

Gambar 6. Perbandingan prestasi tungku dinding cor dengan tungku logam isolator abu.

Dari dua data pengujian diatas (SC dan $\boldsymbol{\eta}$ ), dapat diketahui bahwa modifikasi tungku dengan dinding dari cor semen masih lebih tinggi efisiensinya dibandingkan dengan tungku tradisional. Meskipun jika dibandingkan dengan tungku logam dengan isolator abu kayu (Gambar 6), masih lebih rendah efisiensinya, namun tungku ini mempunyai keunggulan ditinjau dari kontruksi dan kemudahan pembuatannya. Sehingga tungku dinding cor semen ini masih layak untuk diterapkan di masarakat pedesaan dan industri kecil.

\section{KESIMPULAN}

Dari data dan analisis diatas dapat disimpulkan sebagai berikut:

1) Konsumsi spesifik (92 gr/lt) dan efisiensi tungku terbaik (20\%) terjadi pada penggunaan kayu kering (kelembaban $16 \%)$ dan berlangsung pada operasi tungku panas serta pengujian dengan panci kecil $(29 \mathrm{~cm})$.

2) Prestasi tungku dengan dinding cor semen $(\boldsymbol{\eta}=16 \%$ s.d $20 \%)$ masih lebih rendah dari pada tungku logam dengan isolator abu kayu $(\boldsymbol{\eta}=26 \%)$ namun masih lebih tinggi dari pada prestasi tungku tradisional $(\boldsymbol{\eta}=13 \%)$.

3) Mengacu pada dua kesimpulan diatas, maka tungku dengan dinding cor semen ini masih layak untuk diterapkan di masarakat pedesaan dan industri kecil.

\section{DAFTAR PUSTAKA}

[1] Bambang.Y, 2010. “Disain Tungku kayu bakar rendah polusi untuk industri kecil dan masarakat pedesaan.' UNDIP, Semarang.

[2] Baldwin, Samuel,F, 1987, "Biomass stove, engineering design, development dissemination,” Princeton university, USA.

[3] Bryden, Mark,dkk,2002, "Design principles for wood burning cook stove “, Approvecho research center.

[4] Fandi Ahmad, 2011, "Pengaruh tinggi dudukan panci dan rak kayu terhadap efisiensi tungku bahan bakar kayu “. Universitas Diponegoro, Semarang.

[5] F.L. Browne, 2006, "Theories of the combustion of wood and its control”, Forest Products Laboratory, US Departement of Agriculture.

[6] Peter Scott, 2005, "Stove Design and performance“, WHO IAP Workshop, Kampala Uganda.

[7] Voss, John, 2004," Biomass energy for heating and hot water suplly in Belarus,” BTG Biomass energy group BV, Nederland. 